\title{
Studies on the Physico-chemical Parameters of Different Vermicomposts and Vermiwash from Leaf Litter Wastes by Eudrilus eugeniae
}

\author{
B. Esakkiammal* and S. Sornalatha \\ PG and Research Centre, Department of Zoology, Sri Parasakthi College \\ for Women, Courtallam, India \\ *Corresponding author
}

\begin{abstract}
A B S T R A C T
\section{Keywords}

Earthworm, Leaf litter waste, vermicompost,

Eudrilus

Eugeniae.

\section{Article Info}

Accepted:

15 May 2016

Available Online:

10 June 2016

Vermicomposting is the microbial composting of organic wastes through earthworm activity to form organic fertilizer which contains higher level of organic matter, organic carbon, total and available N,P,K and micronutrients. Vermiwash is a liquid collected after a passage of water through a column of worm action and it is very useful as a foliar spray. The physico- chemical properties of vermicomposts showed well marked difference in physical parameters of $\mathrm{PH}$, EC and bulk density. The chemical parameters of $\mathrm{N}, \mathrm{P}, \mathrm{K}$ and micronutrients increased over the initial at the intervals of $30^{\text {th }}$ and $60^{\text {th }}$ days. The physico-chemical parameters of E.eugeniae and E.foetida and reported that E.eugeniae worked vermicompost showed significant increase than other one. The final EC of Eudrilus compost reported was $0.85 \pm 0.09$ in control, $0.91 \pm 0.11$ in E1, $0.96 \pm 0.13$ in E2, $0.87 \pm 0.10$ in E3, $0.88 \pm 0.10$ in E4. The Eudrilus treated compost were increased to slightly alkaline During the experimental period the highest level of nitrogen was recorded in $60^{\text {th }}$ day. The $48 \mathrm{hrs} \mathrm{pH}$ of vermiwash was slightly increase than what it is in $24 \mathrm{hrs}$. All the vermiwash shows slightly alkaline from 7.12-51.The N,P,K,Ca were decreased in $48 \mathrm{hrs}$ vermiwash than in $24 \mathrm{hrs}$. The organic matter and other micronutrients are traced in $28 \mathrm{hrs}$ and $48 \mathrm{hrs}$ vermiwash. Analysis of variance [ANOVA] shows difference between control and experiment. The present study revealed vermicompost and vermiwash may attribute the significant increase and an emphatic effect on macronutrient and micronutrient on plant growth.
\end{abstract}

\section{Introduction}

Vermicomposting is a modified and specialized method of the process uses earthworms to eat and digest farm wastes and turn out high quality in three months or less. Earthworm has a critical influence on soil structure, forming aggregates and improving the physical conditions for plant growth. Vermicompost is a finely divided manure peat like material with high porosity, aeration, drainage and water holding capacity and microbial activity and is stabilized by interaction between earthworms and microorganisms in a nonthermophilic process (Edwards and Burrows, 1988). Vermicomposts are 
products of organic matter degradation through interactions between earthworms and microorganisms (Rincon et al., 2005). Use of vermicompost for horticulture in large scale can solve the problem for disposal of organic wastes and also resolves the deficiency of organic matter in such soils (Alma et al., 2007a). Plant nutrients play a significant role in cell division and differentiation, growth, photosynthetic rate, water-use efficiency, leaf expansion, axillary bud growth, shoot canopy, photosynthetic surface area, carbohydrate utilization and protein synthesis (Atiyeh et al., 2002). Vermiwash is a liquid that is collected after the passage of water through a column of worm action and is very useful as a foliar spray. It is a collection of excretory products and mucus secretion of earthworms along with micronutrients from the soil organic molecules (Ismail, 1997 and Ansari and Sukhraj, 2010). To analyze and compare the physico-chemical parameters of vermicompost and vermiwash from different organic wastes by using exotic earthworms Eudrilus eugeniae.

\section{Materials and Methods}

In this study four types of compost were collected from different leaf litter wastes. The cow dung and leaf litter wastes are used in the ratio 2:1. One serve as control in this $4 \mathrm{~kg}$ of cow dung was used. The wastes are Mangifera indica (E1), Syzygium cumin (E2), Vigna radiata (E3), Vigna mungo (E4). The matured Earthworms, E. eugeniae (Kinberg) were collected from the stock culture and introduce in the wastes. The physical parameter such as $\mathrm{PH}$ was determined by the method of ISI Bulletin (1982). The electrical conductivity manure was determined by the method of Jackson (1973) using the instrument conductivity bridge (type $\mathrm{cm}-82 \mathrm{t}$ ). The bulk density was also determined by the method of Tandon (1993). The organic matter or organic carbon percentage was carried out as per the procedure of ISI Bulletin (1982). The chemical parameters such as the total nitrogen content of the manure were estimated by the Kjeldahl method as per the method suggested by Tandon (1993). Total phosphorus content of the manure was estimated as per Tandon (1993) by colorimetric method. Total potassium content of the manure sample was determined as per Tandon (1993) by flame photometric. The manganese concentration was estimated using spectro photometer model (cl-27) as per the procedure described by Chopra and Kanwar (1991).

\section{Results and Discussion}

In the present study the comparison of results of vermicomposts showed well marked difference in physical parameters of $\mathrm{pH}, \mathrm{EC}$ and bulk density. The nutrition composition revealed that considerable reduction of the organic carbon and increased amount of N, P, K and micronutrients over the initial at the intervals of $30^{\text {th }}$ and $60^{\text {th }}$ days. the $\mathrm{P}^{\mathrm{H}}$ of the $60^{\text {the }}$ day vermicompost prepared from organic wastes mixed with cow dung and control was $7.41+0.41,7.23+0.36 \quad$ (E1), $7.13+0.33 \quad(\mathrm{E} 2), \quad 7.36+0.40(\mathrm{E} 3) \quad$ and $7.14+0.31(\mathrm{E} 4)$.

The $\mathrm{PH}$ of the $60^{\text {th }}$ day vermicompost was increased slightly alkaline when compared to the initial stage. The micronutrients such as calcium, manganese, sulphur, iron, zinc were increased when compared to the control. The bulk density and total organic carbon were decreased during the experimental period. In vermiwash, the EC of the $24 \mathrm{hrs}$ were $3.20+0.10$ in control, $2.34+0.88$ (E1), 2.4+0.10 (E2), 2.6+0.09( $\left.\mathrm{E}_{3}\right)$ and $5.3+0.25\left(\mathrm{E}_{4}\right)$ in E.eugeniae treated vermiwash. The $48 \mathrm{hrs}$ vermiwash was slightly increased than what it is in $24 \mathrm{hrs}$ vermiwash. 
Int.J.Curr.Microbiol.App.Sci (2016) 5(6): 377-383

Table.1 Physico-Chemical parameters of three different composting systems on initial stage

\begin{tabular}{|c|c|c|c|c|c|}
\hline Parameters & Control & $\mathbf{E 1}$ & $\mathbf{E 2}$ & $\mathbf{E 3}$ & E4 \\
\hline pH & $6.10 \pm 0.15$ & $6.01 \pm 0.16$ & $6.52 \pm 0.17$ & $6.66 \pm 0.20$ & $6.71 \pm 0.21$ \\
\hline $\begin{array}{l}\text { Electrical } \\
\text { Conductivity }\left(\mathrm{dsm}^{-1}\right)\end{array}$ & $0.57 \pm 0.006$ & $0.61 \pm 0.009$ & $0.79 \pm 0.07$ & $0.67 \pm 0.03$ & $0.64 \pm 0.02$ \\
\hline $\begin{array}{l}\text { Bulk density } \\
\text { (gms/c.c) }\end{array}$ & $0.557 \pm 0.010$ & $0.507 \pm 0.025$ & $0.533 \pm 0.02$ & $0.652 \pm 0.02$ & $0.674 \pm 0.03$ \\
\hline $\begin{array}{l}\text { Total soluble } \\
\text { solids \% }\end{array}$ & $0.67 \pm 0.009$ & $0.87 \pm 0.066$ & $0.84 \pm 0.06$ & $0.92 \pm 0.63$ & $1.01 \pm 0.11$ \\
\hline $\begin{array}{l}\text { Total Organic } \\
\text { Carbon \% }\end{array}$ & $43.33 \pm 0.54$ & $38.89 \pm 0.91$ & $40.44 \pm 0.41$ & $38.28 \pm 0.38$ & $36.42 \pm 0.23$ \\
\hline Total Nitrogen \% & $1.09 \pm 0.021$ & $1.53 \pm 0.30$ & $1.94 \pm 0.16$ & $2.03 \pm 0.07$ & $2.15 \pm 0.37$ \\
\hline $\begin{array}{l}\text { Total } \\
\text { Phosphorus\% }\end{array}$ & $0.50 \pm 0.007$ & $0.61 \pm 0.05$ & $0.66 \pm 0.18$ & $0.74 \pm 0.13$ & $0.76 \pm 0.08$ \\
\hline Total Potassium\% & $0.45 \pm 0.018$ & $0.65 \pm 0.07$ & $0.60 \pm 0.17$ & $0.8 \pm 0.28$ & $0.82 \pm 0.14$ \\
\hline Total Calcium \% & $0.75 \pm 0.009$ & $1.07 \pm 0.21$ & $1.38 \pm 0.43$ & $1.57 \pm 0.10$ & $1.73 \pm 0.33$ \\
\hline Total Magnesium \% & $0.39 \pm 0.020$ & $0.46 \pm 0.08$ & $0.58 \pm 0.18$ & $0.64 \pm 0.01$ & $0.78 \pm 0.15$ \\
\hline Total sulphur\% & $0.13 \pm 0.009$ & $0.16 \pm 0.01$ & $0.15 \pm 0.01$ & $0.12 \pm 0.34$ & $0.10 \pm 0.01$ \\
\hline Zinc (ppm) & $1113 \pm 0.88$ & $1421 \pm 0.17$ & $1615 \pm 0.34$ & $1012 \pm 0.19$ & $913 \pm 0.66$ \\
\hline $\operatorname{Iron}(\mathbf{p p m})$ & $583 \pm 0.202$ & $645 \pm 0.42$ & $712 \pm 0.19$ & $640 \pm 0.88$ & $844 \pm 0.86$ \\
\hline Manganese (ppm) & $156 \pm 0.57$ & $162 \pm 0.25$ & $145 \pm 0.88$ & $150 \pm 0.12$ & $171 \pm 0.62$ \\
\hline Copper(ppm) & $172 \pm 0.30$ & $176 \pm 0.55$ & $187 \pm 0.21$ & $135 \pm 0.07$ & $162 \pm 0.29$ \\
\hline $\mathrm{C}: \mathrm{N}$ ratio & $39.75 \pm 0.11$ & $25.42 \pm 0.60$ & $20.85 \pm 0.67$ & $18.86 \pm 0.74$ & $16.94 \pm 0.74$ \\
\hline$C: P$ ratio & $86.66 \pm 0.29$ & $63.75 \pm 0.67$ & $61.27 \pm 0.12$ & $51.73 \pm 0.13$ & $47.92 \pm 0.13$ \\
\hline
\end{tabular}


Table.2 Physico-Chemical parameters of three different composting systems on 60th day

\begin{tabular}{|c|c|c|c|c|c|}
\hline Parameters & Control & E1 & E2 & $\mathbf{E 3}$ & E4 \\
\hline pH & $7.41 \pm 0.41$ & $7.23 \pm 0.36$ & $7.13 \pm 0.33$ & $7.36 \pm 0.40$ & $7.14 \pm 0.31$ \\
\hline $\begin{array}{l}\text { Electrical } \\
\left.\text { Conductivity (dsm- }{ }^{1}\right)\end{array}$ & $0.85 \pm 0.09$ & $0.91 \pm 0.11$ & $0.96 \pm 0.13$ & $0.87 \pm 0.10$ & $0.88 \pm 0.10$ \\
\hline $\begin{array}{l}\text { Bulk density } \\
\text { (gms/c.c) }\end{array}$ & $0.14 \pm 0.15$ & $0.13 \pm 0.15$ & $0.15 \pm 0.14$ & $0.21 \pm 0.12$ & $0.24 \pm 0.11$ \\
\hline $\begin{array}{l}\text { Total soluble } \\
\text { solids \% }\end{array}$ & $2.72 \pm 0.68$ & $2.40 \pm 0.58$ & $2.44 \pm 0.59$ & $2.08 \pm 0.47$ & $2.68 \pm 0.67$ \\
\hline $\begin{array}{l}\text { Total Organic } \\
\text { Carbon \% }\end{array}$ & $30.21 \pm 0.99$ & $28.22 \pm 0.97$ & $29.45 \pm 0.77$ & $26.47 \pm 0.45$ & $20.33 \pm 0.24$ \\
\hline Total Nitrogen \% & $3.12 \pm 0.69$ & $3.57 \pm 0.84$ & $3.88 \pm 0.95$ & $4.0 \pm 0.90$ & $3.90 \pm 0.95$ \\
\hline Total Phosphorus\% & $1.65 \pm 0.38$ & $1.72 \pm 0.40$ & $1.86 \pm 0.45$ & $1.87 \pm 0.45$ & $1.94 \pm 0.47$ \\
\hline Total Potassium \% & $1.26 \pm 0.29$ & $1.31 \pm 0.30$ & $1.30 \pm 0.30$ & $1.42 \pm 0.33$ & $1.74 \pm 0.45$ \\
\hline Total Calcium \% & $2.02 \pm 0.43$ & $2.62 \pm 0.63$ & $2.78 \pm 0.68$ & $3.85 \pm 0.01$ & $3.92 \pm 0.03$ \\
\hline Total Magnesium \% & $1.24 \pm 0.30$ & $1.33 \pm 0.33$ & $1.79 \pm 0.49$ & $2.10 \pm 0.06$ & $2.32 \pm 0.66$ \\
\hline Total sulphur\% & $0.32 \pm 0.07$ & $0.34 \pm 0.8$ & $0.36 \pm 0.08$ & $0.22 \pm 0.04$ & $0.26 \pm .05$ \\
\hline Zinc (ppm) & $1544 \pm 0.14$ & $1762 \pm 0.22$ & $1954 \pm 0.28$ & $2014 \pm 0.30$ & $2010 \pm 0.30$ \\
\hline Iron(ppm) & $648 \pm 0.21$ & $987 \pm 0.13$ & $1021 \pm 0.15$ & $1042 \pm 0.12$ & $1021 \pm 0.16$ \\
\hline Manganese (ppm) & $213 \pm 0.20$ & $221 \pm 0.23$ & $230 \pm 0.25$ & $192 \pm 0.13$ & $202 \pm 0.16$ \\
\hline Copper(ppm) & $210 \pm 0.97$ & $217 \pm 0.10$ & $231 \pm 0.20$ & $247 \pm 0.25$ & $233 \pm 0.20$ \\
\hline $\mathrm{C}: \mathrm{N}$ ratio & $9.68 \pm 21$ & $7.90 \pm 0.23$ & $7.59 \pm 0.24$ & $6.62 \pm 0.11$ & $5.21 \pm 0.57$ \\
\hline C:P ratio & $18.31 \pm 0.13$ & $16.41 \pm 0.56$ & $15.83 \pm 0.32$ & $14.16 \pm 0.22$ & $10.48 \pm 0.25$ \\
\hline
\end{tabular}


Table.3 Analysis of Physico -Chemical Parameters of Vermiwash Obtained from Two Different Hours

\begin{tabular}{|c|c|c|c|c|c|c|c|c|c|c|}
\hline \multirow[b]{2}{*}{ PARAMETERS } & \multicolumn{5}{|c|}{ 24- HOURS } & \multicolumn{5}{|c|}{ 48-HOURS } \\
\hline & Control & E1 & E2 & E3 & $\mathbf{E 4}$ & Control & E1 & E2 & E3 & E4 \\
\hline $\mathrm{P}^{\mathrm{H}}$ & $7.12 \pm 0.52$ & $7.42 \pm 0.30$ & $7.14 \pm 0.22$ & $7.40 \pm 0.10$ & $7.28 \pm 0.5$ & $7.32 \pm 0.25$ & $7.51 \pm 0.38$ & $7.12 \pm .22$ & $7.38 \pm 0.55$ & $7.41 \pm 0.82$ \\
\hline $\begin{array}{l}\text { Electrical } \\
\text { Conductivity } \\
\left(\mathrm{dsm}^{-1}\right)\end{array}$ & $3.20 \pm 0.10$ & $2.34 \pm 0.88$ & $2.4 \pm 0.10$ & $6.2 \pm 1.0$ & $5.3 \pm 0.25$ & $3.40 \pm 0.52$ & $3 \pm 0.07$ & $1.3 \pm 0.23$ & $3.2 \pm 0.32$ & $2.6 \pm 0.22$ \\
\hline Nitrogen (ppm) & $77 \pm 0.02$ & $85 \pm 0.98$ & $119 \pm 0.09$ & $102 \pm 0.14$ & $102 \pm 0.55$ & $88 \pm 0.07$ & $20 \pm 0.42$ & $119 \pm 0.93$ & $153 \pm 0.14$ & $85 \pm 0.18$ \\
\hline $\begin{array}{l}\text { Phosphoru } \\
\text { (ppm) }\end{array}$ & $89 \pm 0.25$ & $97 \pm 0.08$ & $103 \pm 0.5$ & $68 \pm 0.08$ & $57 \pm 0.58$ & $62 \pm 0.03$ & $80 \pm 0.93$ & $57 \pm 0.82$ & $74 \pm 0.71$ & $57 \pm 0.42$ \\
\hline Potassium(ppm) & $550 \pm 0.76$ & $675 \pm 0.21$ & $562 \pm 0.5$ & $105 \pm 00.13$ & $735 \pm 0.25$ & $320 \pm 0.10$ & $310 \pm 0.51$ & $121 \pm 0.50$ & $405 \pm 0.90$ & $228 \pm 0.83$ \\
\hline Zinc(ppm) & $100 \pm 0.87$ & $120 \pm 0.02$ & $110 \pm 0.09$ & $150 \pm 0.90$ & $140 \pm 0.30$ & $78 \pm 0.03$ & $200 \pm 0.07$ & $510 \pm 0.01$ & $140 \pm 0.13$ & $140 \pm 0.91$ \\
\hline Calcium(ppm) & $100 \pm 0.43$ & $214 \pm 0.03$ & $97 \pm 0.04$ & $449 \pm 0.71$ & $278 \pm 0.93$ & $82 \pm 0.02$ & $86 \pm 0.03$ & $107 \pm 0.02$ & $128 \pm 0.08$ & $86 \pm 0.10$ \\
\hline $\begin{array}{l}\text { Magnesium(pp } \\
\mathrm{m})\end{array}$ & $143 \pm 0.33$ & $273 \pm 0.04$ & $183 \pm 0.03$ & $126 \pm 0.23$ & $130 \pm 0.50$ & $58 \pm 0.25$ & $117 \pm 0.10$ & $65 \pm 0.72$ & $65 \pm 0.14$ & $104 \pm 0.05$ \\
\hline $\begin{array}{l}\text { Organic } \\
\text { matter }\end{array}$ & Trace & Trace & Trace & Trace & Trace & Trace & Trace & Trace & Trace & Trace \\
\hline
\end{tabular}


Biological conditioning of wastes through vermicomposting might be a boon to developing countries in the utilization of organic wastes for use in organic pollution abatement by rapid reduction in wastes bulk density and elimination of fowl odours (Abbasi, 1998). Of the total nitrogen excreted by worms, about another half is secreted as mucoproteins by gland cells found in the epidermis, and half in the form of ammonia, urea and possibly uric acid as allantoin in a fluid excreted form the nephridiopores (Edwards and Lofty, 1977). (Manimegala et al., 2008; and Manivannan et al., 2012) which had reported increase $\mathrm{P}$ content in the vermicompost than the original un ingested feed material. The micro macro nutrients were available in significant quantity (Esakkiammal, 2015). When organic wastes passes through the gut of worm some quantity of organic minerals are converted into more available forms through the action of enzymes produced by gut associated micro flora. The increase of calcium in the vermicomposts might be due to the excretion of calcium from the calciferous glands. The vermiwash and vermicompost were found to improve the trace element content of the soil. However the combination of these was found to be more effective in improving soil micronutrients content. These vermiwash and vermicompost contribute macronutrients and micronutrients in amount that is required by plants. Vermiwash has great growth promoting as well as pest killing properties (Buckerfield et al., 1999).

\section{References}

Abbasi, S.A. 1998.Weeds of despair, and hope. In: wetlands of India. New Delhi: Publishing House, 12-21.

Alam, M.N., Jahan, M.S., Ali, M.K., Islam, M.S., S.M. Khandaker. 2007. Effect of vermicompost and
NPKS Fertilizers on growth, yield and yield components of red amaranth. Aust. J. Basic Appl. Sci., 1: 706-716.

Ansari, A.A., Kumar Sukhraj. 2010. Effect of vermiwash and vermicompost on soil parameters and productivity of okra (Abelmoschus esculentus) in Guyana. Afr. J. Agric. Res., 5(14): pp.1794-1798.

Arancon, N.Q., Edwards, C.A., Atiyeh, R.M., Metzger, J.D. 2004. Effects of vermicomposts produced from food waste on greenhouse peppers. Biores. Technol., 93: 139-144.

Atiyeh, R.M., Arancon, N., Edwards, C.A., J.D. Metzger. 2002. The influence of earthworm -processed pig manure on the growth and productivity of marigolds. Biores. Technol., 81: 103108.

Buckerfield, J.C., Flavel, T., Lee, K.E., K.A.Webster. 1999. Vermicompost in solid and liquid orm as plant growth promoter. Pedobiolgia, 43: 753-759.

Chopra, S.L., J.S. Kanwar. 1991. Analytical Agricultural Chemistry, 4th Edition, Kalyani Publishers, New Delhi.

Edwards, C.A., I. Burrows. 1988. The potential of earthworm composts as plant growth media. In: Edwards, C.A and Neuhauser, (Eds.), Earthworm in Environmental and waste Management. SPB Academic publishers, The Netherlands: 211220.

Edwards, C.A., J.R. Lofty. 1977. Biology of Earthworms ( $2^{\text {nd }}$ edn), Chapman \& Hall, London.333pp.

Esakkiammal, B. Physico- chemical parameters of different vermicomposts and vermiwash from selected leaf litter wastes. Venture Int. J. Biol. Sci., Vol: 1(2): 107111. 
Ismail, S.A. 1997. Vermicology: The biology of Earthworms .Orient Longman Limited, Chennai.

Manimegla, G., Sarojini, S., Gunasekaran, G., Prakash, M., Parthasarathi, k., Ananthakrishnasamy. 2008. Role of Leucaena glauca leaf litter on the growth and reproduction of earthworms Eisenia foetida savigny. CMU. J. Nat. Sci., 7(2): 295-306.

Manivannan, S., M. Anbalagan. 2012. Effect of Organic additives on the microbial population \& humic and production during recycling of fly ash through vermibiotechnology. Int. J. Res. Environ. Sci. Technol., 2(4): 96-100.

\section{How to cite this article:}

Esakkiammal, B., and Sornalatha, S. 2016. Studies on the Physico-chemical Parameters of Different Vermicomposts and Vermiwash from Leaf Litter Wastes by Eudrilus eugeniae. Int.J.Curr.Microbiol.App.Sci. 5(6): 377-383. doi: http://dx.doi.org/10.20546/ijcmas.2016.506.043 